ARAŞTIRMA / RESEARCH

\title{
The assessment of the pituitary volume in normal prepubertal children with three-dimensional MRI
}

\author{
Normal prepubertal çocuklarda hipofiz hacminin üç boyutlu MRG ile \\ değerlendirilmesi \\ İlknur Okur Akşan1 1 , Ahmet Sar1 1 iD
}

${ }_{1}^{1}$ Karadeniz Teknik Üniversitesi Tip Fakültesi, Radyoloji Bölümü, Trabzon, Turkey

\begin{abstract}
Cukurova Medical Journal 2021;46(3):912-919
Abstract

Purpose: The aim of the present study is to measure the pituitary volume of the children who are under 12 years of age with normal pituitary function and find the reference interval of the normal pituitary volume in the prepubertal period

Materials and Methods: A total 240 healthy children (120 boys- 120 girls) under the age of $12 \mathrm{yr}$ who came our clinic for cranial MRI imaging for various indications within 2 years, were examined. The volume of pituitary gland was measured using a thin-section three dimensional magnetic resonance imaging (MRI) sequences of magnetization-prepared rapid gradient echo imaging with a $1-\mathrm{mm}$ thick reconstructed sagittal images. We also examined the midline sagittal T1-weighted images for the measurement of the pituitary height

Results: The pituitary gland volume and heigh demonstrated increasing trend with the age for both genders in the prepubertal period. Although the pituitary volume in the neonatal period is higher in boys than in girls, it became opposite with the age of $6 \mathrm{yr}$. The height of the pituitary gland increases gradually-slowly with age; while it was higher in boys in the neonatal period, it was higher in girls at the age of 4 years. The lowest, highest and average values of the volume and height values of pituitary gland were found for each age and gender. The reference values of the pituitary volume values containing 5-10-2550-75-90-95th percentiles were formed for each age and gender.

Conclusion: 3D MRI can be used for direct measurement

Öz

Amaç: Çalışmanın amacı normal hipofiz fonksiyonu olan 12 yas altı kız ve erkeklerin hipofiz hacmini ölçmek ve prepubertal dönemde normal hipofiz hacminin referans aralığını bulmaktır.

Gereç ve Yöntem: İki yıl içinde çeşitli endikasyonlarla kraniyal MRG görüntülemesi için kliniğimize gelen, 12 yaş altı toplam 240 sağlıklı çocuk (120 erkek-120 kız) incelendi. Hipofiz bezi hacmi, $1 \mathrm{~mm}$ kalınlığındaki rekonstrükte sagittal imajlarla ince kesitli üç boyutlu mprage gradient eko MRG sekansları kullanılarak ölçüldü. Ayrıca hipofiz bezi yüksekliğinin ölçümü için orta hat sagital T1 ağırlıklı görüntüler inceledik.

Bulgular: Prepubertal dönemde her iki cinsiyet için hipofiz bezi hacmi ve yüksekliğinde yaşla birlikte artış gösterildi. Neonatal dönemde hipofiz hacmi erkeklerde kızlara göre daha yüksek olmasına ragmen; 6 yaşla bu tam tersi oldu. Hipofiz bezi yüksekliği yașla kademeli-yavaş artış göstermekte olup; neonatal peryodda erkeklerde daha yüksekken 4 yaşla birlikte kızlarda daha yüksek olmuştur. Hipofiz bezinin hacim ve yükseklik değerlerinin en düşük, en yüksek ve ortalama değerleri her yaş ve cinsiyet için bulunmuştur. Her yaș ve cinsiyet için 5-10-25-50-75-90-95 persentil içeren hipofiz hacim değerlerinin referans değerleri oluşturulmuştur.

Sonuç: Prepubertal çocuklarda hipofiz hacminin doğrudan ölçümü için üç boyutlu MRG kullanılabilir. Bu 3 boyutlu teknik kullanarak hipofiz hacminin ölçümü, hipofiz bezi gelișiminin çocuklarda daha kesin bir șekilde değerlendirilmesine izin verebilir.
\end{abstract} of pituitary volume in prepubertal children. Measuring of pituitary volume using this $3 \mathrm{D}$ technique may permit a more precise assessment of the developing pituitary gland in children.

Keywords:. prepubertal çocuk, hipofiz bezi hacmi, üç boyutlu MRG
Anahtar kelimeler: prepubertal children, pituitary gland volume, 3D MRI

Yazışma Adresi/Address for Correspondence: Dr. İlknur Okur Akşan, Karadeniz Teknik Üniversitesi Tip Fakültesi, Radyoloji Bölümü, Trabzon, Turkey E-mail: okurilknur@hotmail.com

Geliş tarihi/Received: 17.03.2021 Kabul tarihi/Accepted: 09.06.2021 Çevrimiçi yayın/Published online: 23.07.2021 


\section{INTRODUCTION}

In recent years, some diseases have increased dramatically with the use of MRI in the evaluation of neurological and endocrine disorders in children. Small anatomical structures of human body were shown with the advancement of MRI technology in image resolution. The volume of the organs can be calculated especially with three-dimensional (3D) imaging. Despite this, there is an absence of useful reference data for the normal range of pituitary volumes in children ${ }^{1,2}$.

Nowadays pituitary MRI examination is a basic method in the children with growth deficiency and endocrine disorders ${ }^{1,3}$. Notwithstanding the frequent clinical use of MRI, recognition of abnormalities in pituitary size can be difficult, and radiological reports of pituitary gland size are frequently based on subjective judgment. The size and shape of the normal pituitary gland vary considerably and are also affected by age, gender and hormonal environment ${ }^{4,5,6,7}$. The most dramatic changes are seen in the neonatal period and in puberty $7,8,9,10,11$.

Many studies which were about volume of pituitary gland were using 2D MRI and also most of them are in adult population. These studies mainly used only one plane (usually gland height) $4,5,6,7$ or rough approximations of volumes calculated (volume = height $\mathrm{x}$ width $\mathrm{x}$ length/2) from the two-dimensional data in a indirect way ${ }^{12}$. This measurement is valid in ellipsoid shaped glands and it has not been studied with sufficient details due to the fact that it may sometimes cause mistakes 13,14 . For this reason we used thin section MRI sequences, on which the pituitary volume can be measured directly.

The aim of our study is to correctly calculate the pituitary volume in the children with normal endocrine function in prepubertal period by 3D MRI and establish the normal reference interval. This study may be helpful for paediatricians in the evaluation of patients with neuroendocrine disease, especially growth hormone deficiency.

\section{MATERIALS AND METHODS}

288 children under the age of $12 \mathrm{yr}$ who came to our clinic for cranial MRI imaging for various indications within 2 years, were recruited. All patients with any clinical phenomenon or story about endocrine anomaly, genetic syndrome, preterm birth story under 35 weeks, birth asphyxia, brain injury, craniospinal radiation or abnormal MRI findings in the brain were excluded from the study. After application of these exclusion criteria, 240 children (120 boys- 120 girls) under 12 years of age with normal pituitary function were included in the study. The study was performed in accordance with the ethical guidelines. Approval was received from the ethics committee on Faculty of Medicine, Karadeniz Technical University (approval no: 2013-121 / 03.03.2014) Written informed consent was obtained from all parents/guardians before the child's participation.

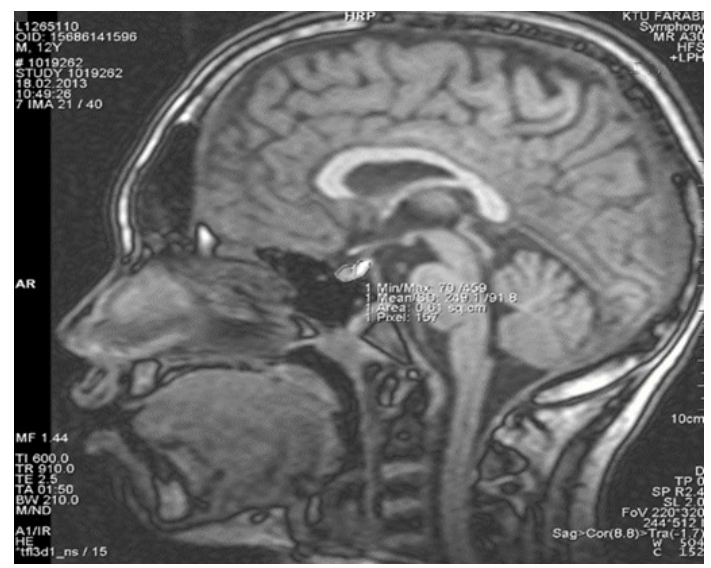

Figure 1. a Sagittal T1-weighted MRI image shows pituitary volume measurement

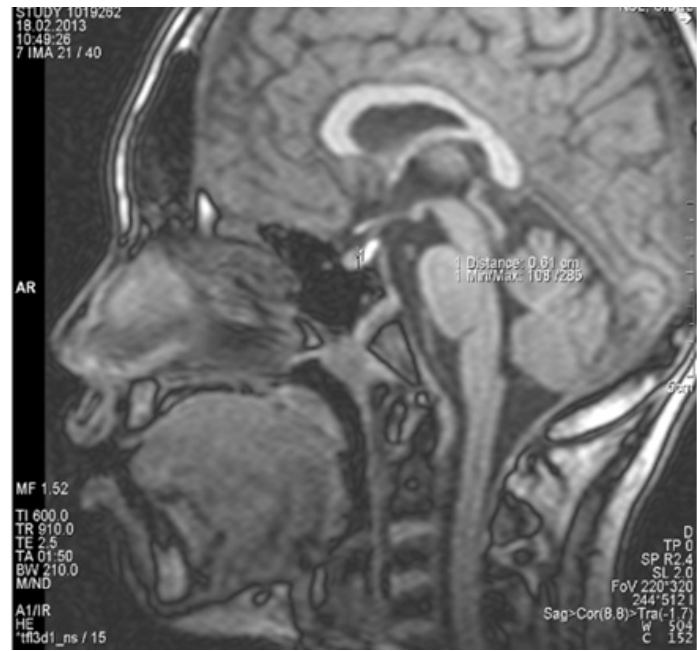

Figure 1. b Sagittal T1-weighted MRI image shows pituitary height measurement 


\section{MRI imaging protocol}

MRI was performed using1.5-T MRI device (Siemens, Magnetom, Symphony, Siemens Medical Systems, Erlanger, Germany) by using the head coil with circular polarization. The volume of pituitary gland was measured using a thin-section three dimensional magnetic resonance imaging (MRI) sequences of magnetization-prepared rapid gradient echo imaging with a 1-mm thick reconstructed sagittal images (TR/TE: 910/2.48, matrix: 256x122, FOV: 247, flip angle: 15, section thickness: $1 \mathrm{~mm}$, section number:40).

\section{Measurement technique of pituitary volume}

MRI scans were processed with MAGNETOM Symphony system (Siemens). In all the cases, the volume was measured on the sagittal image as the boundary is simple to define in this orientation. The regions of interest (ROI) were determined layer-bylayer with manual tracing using a mouse-guided cursor so, pixel number was found (Figure 1.a). The hyperintense posterior pituitary was included in all measurements of the entire gland. Afterwards; voxel volume and pixel number were multiplied and the section volume was measured. Finally, the total volume of the sections was added and total pituitary volume was found.

In the measurement of the pituitary height, the value in which the pituitary superior-inferior distance was measured as the highest was taken in the midsagittal image and the stalk was entered in the section within the sagittal T1A images (Figure 1.b).

\section{Statistical analysis}

All the data were entered by coding in SPSS 13.0 package program (Statistical package program for the Social Sciences). Minimum, maximum, average values, standard deviations and standard errors of the pituitary volume and height values were calculated. Reference values containing the 5-10-25-50-75-9095th percentiles of the pituitary volume were formed for each age and gender and zone normogram was formed. The conformity of the data to normal distribution was assessed with Kolmogorog-Smirnov test. The data not having any normal distribution were analysed with Spearman correlation test and their $\mathrm{R}$ coefficients and $\mathrm{p}$ values were calculated. Those whose $\mathrm{p}$ values are less than 0.05 were accepted as statistically meaningful. Regression coefficient were calculated by conducting regression analysis between the pituitary volume and height separately for girls and boys and the regression equations were attained.

\section{RESULTS}

A total of 240 children (120 boys and 120 girls) including 10 children from all age and gender groups under the age of 12 were analysed. An increase was observed in the pituitary volume and height with the age in the children with normal endocrine function. The lowest, highest and average values of the pituitary volume and height were found for each age and gender (Table 1-2-3-4). The reference values containing 5-10-25-50-75-90-95th percentiles of the pituitary volume values were formed for each age and gender (Table 5).

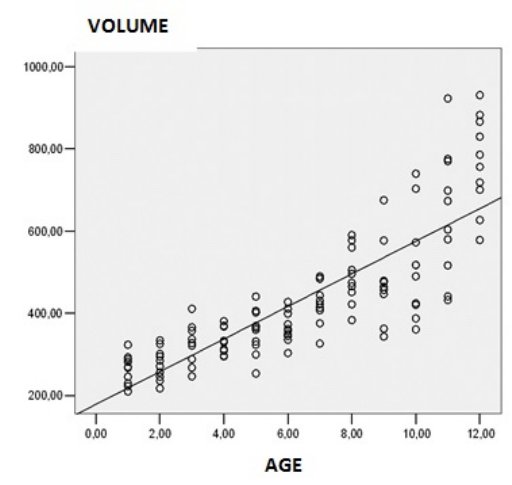

Figure 2.a Relation between pituitary volume and age in girls

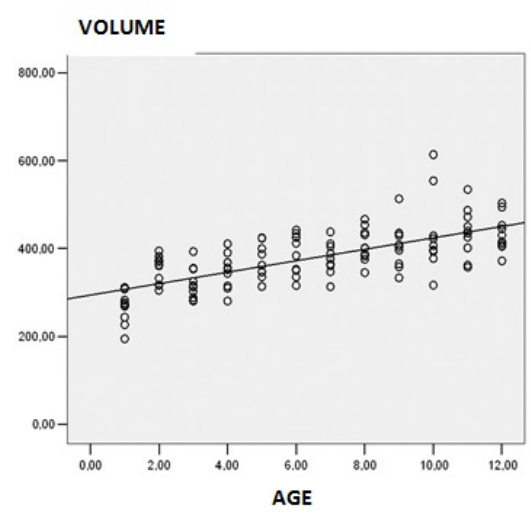

Figure 2.b. Relation between pituitary volume and age in boys

The pituitary gland volume in boys was found higher than girls in first 6 years of life; from the age of $6 \mathrm{yr}$, the pituitary volume observed higher in girls. The 
average volume value of 120 girls was found 436.7 $\mathrm{mm} 3 \pm 165.4(\min 210.2, \max 931.0)$ and the average volume value of 120 boys was found $378.8 \mathrm{~mm} 3 \pm$ 65.8 (min 194.5, $\max 614.1$ ). A meaningful increase was observed in the pituitary volume with the age in girls (R2=0.792, $\mathrm{p}<0,001$ ) (Figure 2I.a). Also, a meaningful increase was observed in the pituitary volume with the age in boys $(\mathrm{R} 2=0.499, \mathrm{p}<0,001)$ (Figure 2I.b).

The pituitary gland height showed gradually-slowly increase with the age and the pituitary height in boys was observed higher than girls in first 4 years of life; from the age of $4 \mathrm{yr}$, it was observed higher in girls; from the age of $4 \mathrm{yr}$, it was observed higher in girls. The average height value of 120 girls was found 5.7 $\mathrm{mm} \pm 1.17(\min 4.0, \max 8.0)$ and the average volume value of 120 boys was found $5.4 \mathrm{~mm} \pm 0.86(\min 3.5$, max 7.5). Up to the age of $12 \mathrm{yr}$, maximum pituitary height was found as $8 \mathrm{~mm}$ in girls and as $7,5 \mathrm{~mm}$ in boys. A meaningful increase was observed in the pituitary height with the age in girls $(\mathrm{R} 2=0.822, \mathrm{p}<$ 0,001) (Figure 3.a). Also, a meaningful increase was observed in the pituitary height with the age in boys $(\mathrm{R} 2=0.657, \mathrm{p}<0,001)$ (Figure 3.b). It was found that the pituitary volume and height values meaningfully increase with the age for both genders in prepubertal period. (Figure 2, Figure 3).

Table 1. Distribution of the pituitary volume $(\mathrm{mm} 3)$ in girls according to age

\begin{tabular}{|l|c|c|c|c|c|c|}
\hline \multicolumn{7}{|c|}{ Gender (Girls ) } \\
\hline Month & No & Frequency (\%) & Average & Std. Deviation & Min. & Max. \\
\hline $0-12$ & 10 & 8.3 & 263.5 & 35.7 & 210.2 & 323.8 \\
\hline $13-24$ & 10 & 8.3 & 277.0 & 38.3 & 217.5 & 334.4 \\
\hline $25-36$ & 10 & 8.3 & 321.5 & 49.6 & 247.0 & 411.2 \\
\hline $37-48$ & 10 & 8.3 & 336.5 & 32.9 & 295.7 & 381.3 \\
\hline $49-60$ & 10 & 8.3 & 355.3 & 55.1 & 253.9 & 441.1 \\
\hline $61-72$ & 10 & 8.3 & 366.5 & 37.5 & 303.6 & 427.8 \\
\hline $73-84$ & 10 & 8.3 & 428.1 & 51.9 & 326.6 & 490.3 \\
\hline $85-96$ & 10 & 8.3 & 492.8 & 67.6 & 383.6 & 590.6 \\
\hline $97-108$ & 10 & 8.3 & 476.2 & 95.2 & 343.6 & 675.2 \\
\hline $109-120$ & 10 & 8.3 & 513.6 & 127.7 & 361.1 & 739.9 \\
\hline $121-132$ & 10 & 8.3 & 641.5 & 157.2 & 432.4 & 922.7 \\
\hline $133-144$ & 10 & 8.3 & 767.8 & 113.7 & 578.6 & 931.0 \\
\hline Total & 120 & 100 & 436.7 & 165.4 & 210.2 & 931.0 \\
\hline
\end{tabular}

Table 2. Distribution of the pituitary volume $(\mathrm{mm} 3)$ in boys according to age

\begin{tabular}{|l|c|c|c|c|c|c|}
\hline \multicolumn{7}{|c|}{ Gender (Boys ) } \\
\hline Month & No & Frequency (\%) & Average & Std. Deviation & Min. & Max. \\
\hline $0-12$ & 10 & 8.3 & 269.4 & 38.3 & 194.5 & 311.4 \\
\hline $13-24$ & 10 & 8.3 & 351.6 & 31.2 & 304.9 & 394.6 \\
\hline $25-36$ & 10 & 8.3 & 320.9 & 36.6 & 280.6 & 393.3 \\
\hline $37-48$ & 10 & 8.3 & 349.5 & 39.0 & 280.6 & 410.8 \\
\hline $49-60$ & 10 & 8.3 & 372.8 & 37.6 & 313.7 & 424.5 \\
\hline $61-72$ & 10 & 8.3 & 387.9 & 46.1 & 316.0 & 442.0 \\
\hline $73-84$ & 10 & 8.3 & 376.6 & 35.4 & 313.7 & 437.9 \\
\hline $85-96$ & 10 & 8.3 & 408.2 & 38.0 & 345.4 & 466.9 \\
\hline $97-108$ & 10 & 8.3 & 407.8 & 50.5 & 333.5 & 513.3 \\
\hline $109-120$ & 10 & 8.3 & 430.7 & 87.5 & 316.9 & 614.1 \\
\hline $121-132$ & 10 & 8.3 & 436.5 & 54.4 & 357.5 & 534.5 \\
\hline $133-144$ & 10 & 8.3 & 433.7 & 41.2 & 372.1 & 503.7 \\
\hline Total & 120 & 100 & 378.8 & 65.8 & 194.5 & 614.1 \\
\hline
\end{tabular}


Table 3. Distribution of the pituitary height $(\mathrm{mm})$ in girls according to age

\begin{tabular}{|l|c|c|c|c|c|c|}
\hline \multicolumn{7}{|c|}{ Gender (Girls) } \\
\hline Month & No & Frequency (\%) & Average & Std. Deviation & Min. & Max. \\
\hline $0-12$ & 10 & 8.3 & 4.3 & 0.41 & 4.0 & 5.0 \\
\hline $13-24$ & 10 & 8.3 & 4.2 & 0.35 & 4.0 & 5.0 \\
\hline $25-36$ & 10 & 8.3 & 4.3 & 0.42 & 4.0 & 5.0 \\
\hline $37-48$ & 10 & 8.3 & 4.8 & 0.52 & 4.0 & 5.5 \\
\hline $49-60$ & 10 & 8.3 & 5.2 & 0.25 & 5.0 & 5.5 \\
\hline $61-72$ & 10 & 8.3 & 5.5 & 0.47 & 5.0 & 6.5 \\
\hline $73-84$ & 10 & 8.3 & 5.9 & 0.51 & 5.0 & 6.5 \\
\hline $85-96$ & 10 & 8.3 & 6.4 & 0.55 & 6.0 & 7.5 \\
\hline $97-108$ & 10 & 8.3 & 6.5 & 0.76 & 5.5 & 7.5 \\
\hline $109-120$ & 10 & 8.3 & 6.5 & 0.57 & 6.0 & 7.5 \\
\hline $121-132$ & 10 & 8.3 & 7.2 & 0.58 & 6.5 & 8.0 \\
\hline $133-144$ & 10 & 8.3 & 7.3 & 0.34 & 7.0 & 8.0 \\
\hline Total & 120 & 100 & 5.7 & 1.17 & 4.0 & 8.0 \\
\hline
\end{tabular}

Table 4. Distribution of the pituitary height $(\mathrm{mm})$ in boys according to age

\begin{tabular}{|l|c|c|c|c|c|c|}
\hline \multicolumn{7}{|c|}{ Gender (Boys) } \\
\hline Month & No & Frequency (\%) & Average & Std. Deviation & Min. & Max. \\
\hline $0-12$ & 10 & 8.3 & 4.1 & 0.41 & 3.5 & 4.5 \\
\hline $13-24$ & 10 & 8.3 & 4.5 & 0.43 & 4.0 & 5.0 \\
\hline $25-36$ & 10 & 8.3 & 4.6 & 0.57 & 4.0 & 6.0 \\
\hline $37-48$ & 10 & 8.3 & 4.8 & 0.71 & 4.0 & 6.0 \\
\hline $49-60$ & 10 & 8.3 & 4.9 & 0.15 & 4.5 & 5.0 \\
\hline $61-72$ & 10 & 8.3 & 5.5 & 0.52 & 5.0 & 6.5 \\
\hline $73-84$ & 10 & 8.3 & 5.5 & 0.64 & 5.0 & 6.5 \\
\hline $85-96$ & 10 & 8.3 & 5.9 & 0.31 & 5.5 & 6.5 \\
\hline $97-108$ & 10 & 8.3 & 6.0 & 0.49 & 5.0 & 7.0 \\
\hline $109-120$ & 10 & 8.3 & 6.4 & 0.55 & 6.0 & 7.5 \\
\hline $121-132$ & 10 & 8.3 & 5.9 & 0.59 & 5.0 & 7.0 \\
\hline $133-144$ & 10 & 8.3 & 6.2 & 0.35 & 6.0 & 7.0 \\
\hline Total & 120 & 100 & 5.4 & 0.86 & 3.5 & 7.5 \\
\hline
\end{tabular}

Table 5. Reference values of pituitary gland volüme for each age and gender

\begin{tabular}{|c|c|c|c|c|c|c|c|c|c|c|c|c|}
\hline & \multicolumn{12}{|c|}{ Percentiles } \\
\hline & \multicolumn{12}{|c|}{ Gender } \\
\hline & \multicolumn{6}{|c|}{ Girls } & \multicolumn{6}{|c|}{ Boys } \\
\hline Age & 5 & 10 & 25 & 50 & 75 & 90 & 5 & 10 & 25 & 50 & 75 & 90 \\
\hline 1 & 210.2 & 211.5 & 228.2 & 268.8 & 290.0 & 320.7 & 194.5 & 197.8 & 239.5 & 274.3 & 308.6 & 311.2 \\
\hline 2 & 217.5 & 219.4 & 243.6 & 278.3 & 307.4 & 333.5 & 304.9 & 306.1 & 317.1 & 362.0 & 376.3 & 393.4 \\
\hline 3 & 247.0 & 249.1 & 283.7 & 324.7 & 359.9 & 406.7 & 280.6 & 280.8 & 287.0 & 314.1 & 354.0 & 3894 \\
\hline 4 & 295.7 & 295.8 & 306.0 & 331.6 & 368.7 & 380.2 & 280.6 & 283.5 & 313.8 & 354.2 & 373.9 & 408.7 \\
\hline 5 & 253.9 & 258.5 & 317.8 & 362.7 & 403.1 & 437.6 & 313.7 & 315.9 & 343.7 & 374.6 & 406.0 & 424.4 \\
\hline 6 & 303.6 & 306.8 & 342.7 & 359.4 & 4023 & 426.1 & 316.0 & 317.9 & 346.7 & 398.1 & 428.7 & 441.2 \\
\hline 7 & 326.6 & 331.5 & 399.9 & 426.6 & 484.6 & 489.8 & 313.7 & 317.0 & 357.6 & 370.5 & 405.9 & 435.2 \\
\hline 8 & 383.6 & 387.5 & 444.3 & 485.3 & 564.8 & 589.3 & 345.4 & 348.4 & 381.3 & 401.1 & 440.5 & 465.6 \\
\hline 9 & 343.6 & 345.5 & 426.0 & 470.5 & 503.8 & 665.4 & 333.5 & 335.9 & 363.5 & 405.9 & 434.8 & 505.5 \\
\hline 10 & 361.1 & 363.7 & 412.6 & 503.9 & 605.3 & 736.2 & 316.9 & 323.0 & 390.0 & 401.5 & 460.4 & 608.1 \\
\hline 11 & 432.4 & 433.3 & 497.8 & 638.7 & 771.7 & 908.0 & 357.4 & 357.9 & 391.8 & 437.2 & 475.7 & 529.7 \\
\hline 12 & 578.6 & 583.5 & 682.5 & 771.2 & 870.7 & 926.2 & 372.1 & 375.4 & 405.7 & 423.2 & 463.4 & 502.7 \\
\hline
\end{tabular}




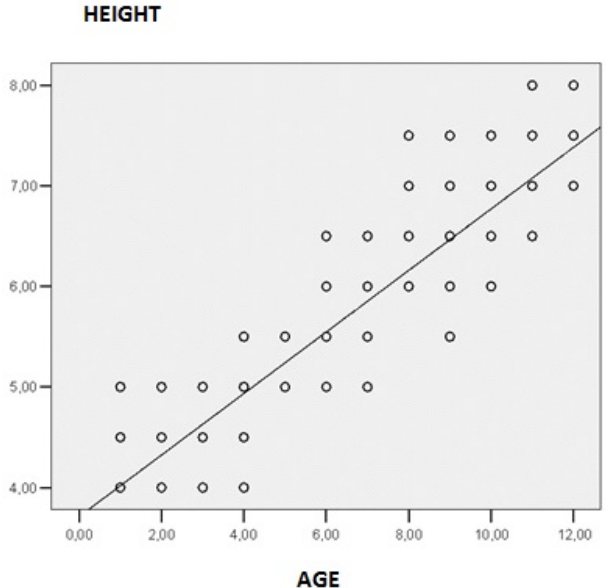

Figure 3.a Relation between pituitary height and age in girls

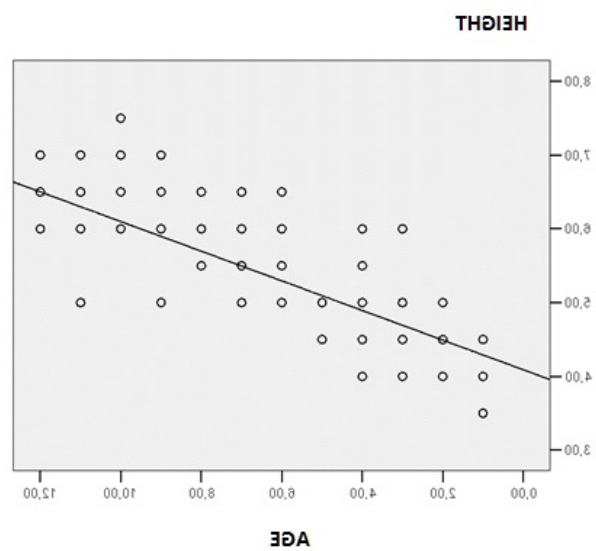

Figure 3.b Relation between pituitary height and age in boys

\section{DISCUSSION}

There isn't any of useful reference data for the normal range of pituitary volumes in children ${ }^{1,2}$. We reported data on measured pituitary volumes of prepubertal children with normal brains and no clinical evidence of pituitary gland lesions. In recent years, with the using of MRI for the evaluation in children, neurological and endocrine disorders has increased dramatically. The advancement of MRI technology supplying us an increase in image resolution and the evaluation of small anatomical structures ${ }^{1,2}$. Although initially the conventional radiography and CT have been used in the assessment of the pituitary volume, correct results could not be reached regarding the volume ${ }^{15,16,17}$. Especially the pituitary height has been measured with the use of 2D MRI and the volume has been assessed with mathematical formulas (volume $=$ height $\mathrm{x}$ width $\mathrm{x}$ length/2)12,18,19. This measurement is valid in ellipsoid shaped glands and it has not been studied with sufficient details due to the fact that it may sometimes cause mistakes ${ }^{13,14}$. For this reason we used thin section MRI sequences, on which the pituitary volume can be measured directly. The measurement of pituitary volume using this $3 \mathrm{D}$ technique should permit a more precise assessment of the developing pituitary gland in children. Although the data are limited in Turkish population because of limitted local region and may not be extrapolated to all groups, the results can probably serve as a standard of reference for pituitary measurements in pediatric patients.

In our study, an increasing pituitary volume and height were observed with the age in the children with normal pituitary function. The pituitary gland volume was found higher in boys more than girls in first 6 years of life; from the age of 6 th $\mathrm{yr}$, the value was observed higher in girls. The pituitary gland height showed gradually-slowly increasing with the age and the pituitary height was observed higher than girls in boys in first 4 years of life; from the age of 4 th $\mathrm{yr}$, it was observed higher in girls.

Takano et.al. ${ }^{20}$ studied 199 prepubertal-pubertal Japanese children,121 of whom were under the 10 yr. The mean prepubertal values were reported in broad age groupings of 0-1, 1-4, 5-9 yr. In this study, pituitary gland volume increased with age; it was found to increase gradually until puberty. In the same study, the pituitary volume, which was higher in girls at the age of $0-1 \mathrm{yr}$, was dominated in boys at the age of 1-4 yr, and it was seen higher again in girls at the age of 5-9 yr. Unlike to our study, pituitary gland volume was found to be higher in boys at the age of 0-1 yr. Similarly with our study, in the present study, the volume of the pituitary gland between the ages of 1-4 yr was dominated in boys and after 6 years of age it was higher in girls. In our study, the measured pituitary volume values were higher than the measured pituitary volume values by Takano et al., particularly in the 5-9 yr age group. We think the variability between two studies by the different ethnic compositions of the study populations and the grouped age intervals. This study also includes a small ethnic group (Japanese population) similar to our study. 
Marziali et.al. ${ }^{21}$ studied the anterior pituitary volume of 95 prepubertal children under $10 \mathrm{yr}$ of age with broad age groupings (2-12 months, 1-4 ages and 5-10 ages). It was observed that anterior pituitary volume increases together with age, this increase was seen the highest values in the first 4 years and there was a lower increasing values seen between the ages 5-10 $\mathrm{yr}^{21}$. In the present study, the measured pituitary volume values are prominent higher than the measured pituitary volume values by Marziali et al., particularly 0-12 months. It is thought that measurement of the anterior gland volume and broad age groupings may lead to this difference. Unlike to our study, only the anterior pituitary gland was measured in this study.

Fink et.al. ${ }^{22}$ studied 139 children up to the age of 10 yr (0-10 ages), but did not take into account gender differences and also contained a wide ethnic group. Also, pituitary volume was measured by the coronal and sagittal reformat images and no meaningful difference was detected between them. In this study, an increase in the prepubertal pituitary gland volume was observed with age, regardless of gender ${ }^{22}$. Although geometric average was used in this study, similar to our study an increasing prepubertal pituitary gland volume with age was seen.

Han et.al. ${ }^{23}$ studied of 75 children between the ages 1-19 yr and were grouped with broad age groupings of 1-4, 5-9, 10-14, 15-19 yr. Similar to our study, pituitary gland volume with height were examined together. Pituitary volume and height were shown an increase with the age also same to our study. The differences with our study, 0-1 age group was not included in this study. In the present study, the measured volume values in both age groups (1-4 and 5-9 ages) and genders are higher than the measured volume values by Han et al., In addition, the measured height values in the present study, are slightly higher than the Han's study. The reason for the difference may be due to ethnic differences or broad age groupings. Also the number of children each groups is the disadvantage of this study ${ }^{23}$

The main limitation of the present study is that it is a single-center study with a relatively small sample size; thus, future, large scale studies are required.

In conclusion, in the present study, 3D MRI was used to evaluate the pituitary gland volume in healthy children. The reference data provided by 3D MRI may be helpful for paediatricians in the evaluation of patients with neuroendocrin disease, especially growth hormone deficiency. With the advent of advanced MRI technology and 3D data acquisition, we recommend replacing indirect estimates of pituitary size and volume with direct volumetric analysis.

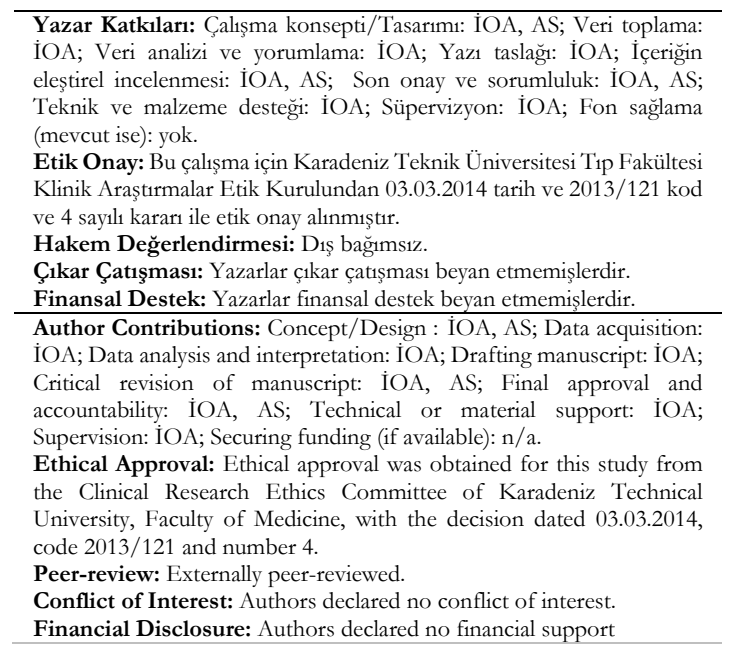

\section{REFERENCES}

1. Bozzola M, Adamsbaum C, Biscaldi I Zecca M, Cisternino M, Genovese E et al.. Role of magnetic resonance imaging in the diagnosis and prognosis of growth hormone deficiency. J Clin Endocrinol. 1996;45:21-6.

2. Kornreich L, Horev G, Lazar L Schwards M, Sulkes J, Pertzalan A. MR findings in growth hormone deficiency: correlation with severity of hypopituitarism. AJNR Am J Neuroradiol. 1998;19:1495-9.

3. Bozzola M, Mengarda F, Sartirana P Tato L, Chaussain JL. Long-term follow-up evaluation of magnetic resonance imaging in the prognosis of permanent GH deficiency. Eur J Endocrinol. 2000;143:493-6.

4. Suzuki M, Takashima T, Kayoda M Konishi H, Kameyama T, Yoshikawa J et al. Height of normal pituitary gland on MR imaging: age and sex differentiation. J Comput Assit Tomogr. 1990;14:369 .

5. Elster AD, Chen MYM, Williams III DW, Key LL. Pituitary gland: MR imaging of physiologic hypertrophy in adolescence. Radiology. 1990;174:681-5.

6. Elster AD, Sanders TG, Vines FS, Chen MYM. Size and shape of the pituitary gland during pregnancy and post partum: measurement with MR imaging. Radiology. 1991;181:531-5.

7. Doraiswamy PM, Potts JM, Axelson DA Husain MM, Lurie $\mathrm{SN}, \mathrm{Na} C$ et al. MR Assessment of pituitary gland morphology in healthy volunteers: age and 
gender-related differences. AJNR Am J Neuroradiol. 1992;13:1295-9.

8. Cox TD, Elster AD. Normal pituitary gland: changes in shape, size and signal intensity during the $1^{\text {st }}$ year of life at MR imaging. Radiology. 1991;179:721-4.

9. Argyropoulou M, Perignon F, Brunelle F, Brauner R, Rappaport R. Height of normal pituitary gland as a function of age evaluated by magnetic resonance imaging in children. Pediatr Radiol. 1991;21:247-9.

10. Tien RD, Kucharczyk J, Bessette J, Middleton M. MR imaging of the pituitary gland in infants and children: changes in size, shape, and MR signal with growth and development. AJR Am J Roentgenol. 1992;158:11514.

11. Elster AD. Modern imaging of the pituitary. Radiology. 1993;187:1Y14.

12. Lurie SN, Doraiswamy PM, Husain MM, Boyko OM, Ellinwood Jr EH, Figiel GS et al. In vivo assessment of pituitary gland volume with magnetic resonance imaging: the effect of age. J Clin Endocrinol Metab. 1990;71:505-8.

13. Hamilton J, Blaser S, Daneman D . MR imaging in idiopathic growth hormone deficiency. AJNR Am J Neuroradiol. 1998; 19:1609-15.

14. Nagel B, Palmbach $M$, Petersen D,Ranke MB. Magnetic resonance images of 91 children with different causes of short stature: pituitary size reflects growth hormone secretion. Eur J Pediatr. 1997;156:758-63.

15. Peyster RG, Hoover ED, Viscarello RR Moshang T, Haskin ME. CT appearance of the adolescent and preadolescent pituitary gland. AJNR Am J Neuroradiol. 1983;4:411-4.

16. Mc Lachlan MS, Williams ED, Fortt RW Doyle FH.
Estimation of pituitary gland dimension from radiographs of the sella turcica. A post mortem study. Br J Radiol. 1968;41:323-30.

17. Pikulev LA, Gerasimov SM, Cheremisin VM. Relationship between the volume of the hypophysis and the volume of the sella turcica (radioanatomic study). Arkh. pat. anat. 1970;59:98-104.

18. Sharafuddin MJ, Luisiri A, Garibaldi LR Fulk DL, Klein JB, Gillespie KN et al. MR imaging diagnosis of central precocious puberty: importance of changes in the shape and size of pituitary gland. AJNR Am J Neuroradiol. 1994;162:1167-73.

19. Tsunoda A, Okuda O, Sato K. MR height of the pituitary gland as a function of age and sex: especially physiological hypertrophy in adolescence and in climacterium. AJNR Am J Neuroradiol. 1997;18:5514.

20. Takano K, Utsunomiya H, Ono H, Ohfu M, Okazaki M. Normal development of the pituitary gland: assessment with three-dimensional MR volumetry. AJNR Am J Neuroradiol. 1999;20:312-5.

21. Marziali S, Gaudiello F, Bozzao A Scire G, Ferone E, Colangelo $\mathrm{V}$ et al. Evaluation of anterior pituitary gland volume in childhood using three-dimensional MRI. Pediatr Radiol. 2004;34:547-51.

22. Fink AM, Vidmar S, Kumbla S Pedreira CC, Kanumakala S, Williams C et al. Age-related pituitary volumes in prepubertal children with normal endocrine function: volumetric magnetic resonance data. J Clin Endocrinol Metab. 2005;90:3274-8.

23. Han X, Xiu J, Huang Z Zhang J, Zhang Z, DongY et al. Three-dimensional magnetic resonance volumetry of the pituitary gland is effective in detecting short stature in children. Exp Ther Med. 2014;8:551-6. 